\title{
PENGKAJIAN SUMBER DAYA MANUSIA TERHADAP TINGKAT PENDAPATAN, PENGETAHUAN, SERTA KESADARAN WAJIB PAJAK DALAM KEPATUHAN MEMBAYAR PBB PADA MASA PANDEMI COVID-19
}

\author{
Sri Indah \\ Email: indahsri729@gmail.com \\ Program Studi Akuntansi Universitas Tribhuwana Tunggadewi Malang \\ Ruth Feotnai Ele Bana \\ Email: rutfeonaielebana@gmail.com \\ Program Studi Akuntansi Universitas Tribhuwana Tunggadewi Malang \\ Adya Hermawati \\ Email: wati_wati38@yahoo.co.id \\ Program Pasca Sarjana Magister Manajemen Universitas Widyagama Malang
}

\begin{abstract}
ABSTRAK
Kepatuhan WP merupakan salah satu keadaan dimana WP yang manan akan secara langsung dapat memenuhi seluruh kewajiban perpajkaan serta dapat membuat atas hal perpajakan. Adapun masalah yang berkesenambungan terhadap kepatuhan WP antara lain pengetahuan, pendapatan serta kesadaran WP. Riset ini bertujuan untuk mengetahui sejauh mana kepatuhan WP yang akan dipengaruhi oleh pengetahuan, pendapatan terhadap kpeatuhan WP pada Kelurahan Polowijen. Dalam riset ini menggunakan metode kuantitatif, adapun jumlah sampel yang digunakan berjumlah 44 orang yang akan dijadikan sebagai responden, sedangkan teknik pengumpulan data yang digunakan dalam riset ini ialah interview, observasi serta kuesioner. Data yang digunakan ialah data sekunder serta primer. Sedangkan teknik analisa data yang akan digunakan dalam riset ini ialah regresi linier berganda, dengan diadakan penguian hipotesis antar varibel.
\end{abstract}

Kata Kunci: Pendapatan, Pengetahuan, Kesadaran, Wajib Pajak, Pajak Bumi dan Bangunan

\begin{abstract}
Taxpayer compliance is one of the conditions in which a safe taxpayer will directly be able to fulfill all tax obligations and can make tax matters. The problems that are continuous with taxpayer compliance include knowledge, income and awareness of taxpayers. This research aims to find out the extent to which taxpayer compliance will be influenced by knowledge, income on taxpayer compliance in Polowijen Village. This research uses quantitative methods, while the number of samples used is 44 people who will be used as respondents, while the data collection techniques used in this research are interviews, observations and questionnaires. The data used are secondary and primary data. While the data analysis technique that will be used in this research is multiple linear regression, with hypothesis testing between variables.
\end{abstract}

Keywords: $\quad$ Income, Knowledge, Awareness, Taxpayer, Land and Building Tax 


\section{PENDAHULUAN}

Pada akhir tahun 2019, dunia dikejutkan dengan munculnya virus Covid-19 yang penyebarannya begitu cepat hingga menyebabkan kematian. Covid-19 ini menyebabkan penurunan perekonomian atau bisnis, investasi maupun pendapatan nasional hampir diseluruh dunia. Pembangunan nasional harus berlangsung secara terus melonjak serta dapat memaksimalkan tingkat kesejahtraan pada masayrakat. Problem pembiayaan biasanya disebabkan oleh pemerintah yang membutuhkan dana yang besar untuk melaksanakan pembangunan nasional. Dana yang dibutuhkan tersebut semakin meningkat seiring dengan peningkatan kebutuhan pembangunan itu sendiri (Amran, 2018).

PBB ialah salah satu pajak yang dimiliki oleh negara yang mana akan dikenakan pada bumi serta bangunan yang tercantumkan dalam UU Tahun 1985 No 12 yang berarti bahwa PBB sebagaimana telah dituangkan dalam UU Tahun 1994 No 12. PBB P2 merupakan sebuah pajak yang akan nikenakan terhadap bumi serta bangunan yang mana akan dimilki serta dapat dikuasai oleh badan serta orang pribadi. Seperti apabila setiap tanah yang mana akan dikuasi oleh pihak badan atau pihak peribadi akan selalu diwajibkan untuk melakukan pembayaran pajak terhadap negara. Pada saat UU Tahun 2009 No 28 yang mana telah diberlakukan terkait retribusi serta perpajakan. Polowijen dikatakan sebagai salah Kelurahan yang berada di Kota Malang Prov Jawa Timur digolongkan menjadi 6 RW serta 38 RT.

Pada saat menjalankan Penagihan (PBB) di Kelurahan Polowijen, permasalahan yang dihadapi adalah dapat dikatakan masih minim dalam pemahaman terkait dengan kepatuhan WP dan ketidak percayaan masyarakat terhadap para administrasi pajak dikarenakan banyaknya persepsi yang menganggap bahwa oknum pajak melakukan korupsi.

(Amran, 2018a) menyatakan bahwa pada variabel kesadaran WP dapat memberikan pengaruh yang secara positif terhadap kepatuhan WP, yang artinya bahwa apabila semakin meningkat pa da tingkat kesadaran yang dimiliki maka secar lang sung jug akan memaksimalkan kepatuhan WP. (Warouw, 2015) juga dapat dikatakan sebagai salah satu sayarat WP yang $\mathrm{m}$ ana bertujuan untuk dapat memenuhi seluh kewajiban dalam perpajakan serta dapat membuat hak atas pajaknya.

Adapun faktor yang mempengaruhi tingkat kesadaran WP ialah pemahaman terhadap WP. Hasil riset yang dialakukan oleh (Isawati, 2016) yang menyatakan bahwa adanya 
sebuah pengaruh yang scara signifikan mengenai pemahaman perpajakan terhadap kepatuhan WP pada saat melakukan pembayaran pajak. Hasil penelitian itu menunjukan bahwa apabila pemahaman atas WP meningkat makan secara tidak langsung tingkat kepatuhan WP pun akan meningkat pula.

Hal lain yang juga menyangkut kepatuhan Wajib Pajak ialah tingkat pendapatan. WP seharusnya mampu melihat kemampuan dalam membayar secara mandiri (Isawati, 2016). Sebagaimana hasil riset ini selaras dengan riset yang dibuat oleh (Amran, 2018a) dapat menyimpulkan bahwa tingkat pendapatan memberikan pengaruh yang secara positif terhadap kepatuhan WP, yang artinya bahwa abila tingakat pendapatan meningkat, maka secara tidak langsung akan memaksimalkan pula kepatuhan WP.

\section{METODE PENELITIAN}

Pada riset ini memiliki riset kuantitatif, sehingga metode kuantitatif dapat dinaytakan salah satu metode riset yang mana akan belandasakan pada limu filsafat, tingkat populasi yang digunakan dalam riset ini berjumlah11.467 orang WP PBB. Pada riset ini salah satu cara dalam penentuan sampel ialah menggunakan random sampling. Teknik pungumpulan data pada riset ini iala dokumentasi, kuesioner serta observasi, informasih yang akan digunakan ialah sekunder serta data primer, sedangkan teknik analisa data yang digunakan ialah regresi linier berganda serta pegujian hipotesisi.

\section{HASIL DAN PEMBAHASAN}

\section{Hasil}

\section{Uji Validitas}

Tabel 1. Uji Validitas

\begin{tabular}{|} 
No Item & rtabel & rhitung & Keterangan \\
\hline \multicolumn{4}{|c|}{ Variabel Pendapatan } \\
\hline X1.1 & 0,297 & 0,583 & Valid \\
\hline X1.2 & 0,297 & 0,816 & Valid \\
\hline X1.3 & 0,297 & 0,724 & Valid \\
\hline X1.4 & 0,297 & 0,745 & Valid \\
\hline Variabel Pengetahuan \\
\hline \multicolumn{4}{|c|}{ X2.1 } & 0,297 & 0,666 & Valid \\
\hline X2.2 & 0,297 & 0,306 & Valid \\
\hline X2.3 & 0,297 & 0,393 & Valid \\
\hline X2.4 & 0,297 & 0,799 & Valid \\
\hline Variabel Kesadaran & 0,516 & Valid \\
\hline X3.1 & 0,297 & 0,542 & Valid \\
\hline X3.2 & 0,297 & 0,563 & Valid \\
\hline X3.3 & 0,297 &
\end{tabular}




\begin{tabular}{|c|c|c|c|}
\hline X3.4 & 0,297 & 0,434 & Valid \\
\hline \multicolumn{3}{|c|}{ Variabel Kepatuhan Wajib Pajak } & Valid \\
\hline X4.1 & 0,297 & 0,744 & Valid \\
\hline X4.2 & 0,297 & 0,878 & Valid \\
\hline X4.3 & 0,297 & 0,744 & Valid \\
\hline X4.4 & 0,297 & 0,307 &
\end{tabular}

Keputusan dimana nilai $\mathrm{r}_{\text {hitung }}$ jauh lebih tingggi dibandingkan dengan nilai $\mathrm{r}_{\text {tabel }}$, sehingga dapat dinyatakan bawa seluruh item pertanyaan yang dilakukan dalam riset ini dinyatakan valid.

\section{Uji Reliabilitas}

Tabel 2. Uji Reliabilitas $\left(\mathrm{X}_{1}\right)$

\section{Reliability Statistics}

\begin{tabular}{r|r}
$\begin{array}{c}\text { Cronbach's } \\
\text { Alpha }\end{array}$ & N of Items \\
\hline .782 & 5 \\
\hline
\end{tabular}

Sebagaimana pada hasil analisa pada tabel tersebut, sehingga dapat diketahui bahwa nilai cronbach's alpha reliabilitas variabel Tingkat Pendapatan $\left(\mathrm{X}_{1}\right)$ adalah sebesar 0,782 . Berdasarkan dasar pengambilan keputusan, maka dapat disimpulkan bahwa variabel Tingkat Pendapatan telah lulus uji reliabilitas.

Tabel 3. Uji Reliabilitas $\left(\mathrm{X}_{2}\right)$

\section{Reliability Statistics}

\begin{tabular}{r|r}
$\begin{array}{c}\text { Cronbach's } \\
\text { Alpha }\end{array}$ & N of Items \\
\hline .701 & 5 \\
\hline
\end{tabular}

Sebagaimana pada hasil analisa pada tabel tersebut, sehingga dapat diketahui bahwa nilai cronbach's alpha reliabilitas variabel Pengetahuan $\left(\mathrm{X}_{2}\right)$ adalah sebesar 0,701 . Berdasarkan dasar pengambilan keputusan, maka dapat disimpulkan bahwa variabel Pengetahuan telah lulus uji reliabilitas.

Tabel 4. Uji Reliabilitas $\left(\mathrm{X}_{3}\right)$

\section{Reliability Statistics}

\begin{tabular}{r|r}
$\begin{array}{c}\text { Cronbach's } \\
\text { Alpha }\end{array}$ & N of Items \\
\hline .640 & 5 \\
\hline
\end{tabular}


Sebagaimana telah dilaukan pengujian pada tebel tersebut, sehingga dapat dinyatakan bahwa nilai cronbach's alpha reliabilitas variabel Kesadaran $\left(\mathrm{X}_{3}\right)$ adalah sebesar 0,640. Berdasarkan dasar pengambilan keputusan, maka dapat disimpulkan bahwa variabel Kesadaran telah lulus uji reliabilitas.

Tabel 5. Uji Reliabilitas (Y)

\section{Reliability Statistics}

\begin{tabular}{c|r}
$\begin{array}{c}\text { Cronbach's } \\
\text { Alpha }\end{array}$ & N of Items \\
\hline .767 & 5 \\
\hline
\end{tabular}

Sebagaimana telah dilaukan pengujian pada tebel tersebut, sehingga dapat dinyatakan bahwa nilai cronbach's alpha reliabilitas variabel Kepatuhan (Y) adalah sebesar 0,767.

Tabel 6. Uji Reliabilitas

\begin{tabular}{|c|c|c|c|}
\hline Item Variabel & Standar Reliabilitas & Nilai Cronbach's Alpha & Keterangan \\
\hline Pendapatan & 0,60 & 0,782 & Reliabel \\
\hline Pengetahuan & 0,60 & 0,701 & Reliabel \\
\hline Kesadaran & 0,60 & 0,640 & Reliabel \\
\hline Kepatuhan & 0,60 & 0,767 & Reliabel \\
\hline
\end{tabular}

Sebagaimana telah dilaukan pengujian pada tebel tersebut, sehingga dapat dinyatakan bahwa keseluruhan item pertanyaan angket atau kuesioner dinyatakan reliabel, hal ini berdasarkan dasar pengambilan keputusan ialah cronbach's alpha $>0,60$.

\section{Uji Asumsi Klasik}

\section{Uji Normalitas}

Tabel 7. Uji Normalitas

\begin{tabular}{|c|c|c|}
\hline \multicolumn{3}{|c|}{ One-Sample Kolmogorov-Smirnov Test } \\
\hline & & $\begin{array}{l}\text { Unstandardiz } \\
\text { ed Residual }\end{array}$ \\
\hline $\mathrm{N}$ & & 44 \\
\hline \multirow[t]{2}{*}{ Normal Parameters ${ }^{a, b}$} & Mean & .0000000 \\
\hline & Std. Deviation & 1.92210337 \\
\hline \multirow[t]{3}{*}{ Most Extreme Differences } & Absolute & .080 \\
\hline & Positive & .062 \\
\hline & Negative & -.080 \\
\hline \multicolumn{2}{|l|}{ Test Statistic } & .080 \\
\hline \multicolumn{2}{|l|}{ Asymp. Sig. (2-tailed) } & $.200^{c, d}$ \\
\hline \multicolumn{3}{|c|}{ a. Test distribution is Normal. } \\
\hline \multicolumn{3}{|c|}{ b. Calculated from data. } \\
\hline \multicolumn{3}{|c|}{ c. Lilliefors Significance Correction. } \\
\hline \multicolumn{3}{|c|}{ d. This is a lower bound of the true significance. } \\
\hline
\end{tabular}

Sebagaimana telah dilaukan pengujian pada tebel tersebut, sehingga dapat dinyatakan bahwa tingkat signifikan dalam riset ini menggunakan uji Asym. Sig 2 tailed sebesar 0,200, 
yang mana jauh lebih bersar dari 0,05, sehingga dengan kesimplannya ialah data yang digunakan berdistribusi normal.

\section{Uji Multikolinearitas}

Tabel 8. Uji Multikolinearitas

Coefficients $^{a}$

\begin{tabular}{|c|c|c|c|c|c|c|c|c|}
\hline \multicolumn{9}{|c|}{ Coefficients $^{\mathrm{a}}$} \\
\hline \multirow[b]{2}{*}{ Model } & & \multicolumn{2}{|c|}{ Unstandardized Coefficients } & \multirow{2}{*}{$\begin{array}{c}\text { Standardized } \\
\text { Coefficients } \\
\text { Beta }\end{array}$} & \multirow[b]{2}{*}{ t } & \multirow[b]{2}{*}{ Sig. } & \multicolumn{2}{|c|}{ Collinearity Statistics } \\
\hline & & B & Std. Error & & & & Tolerance & VIF \\
\hline \multirow[t]{4}{*}{1} & (Constant) & 2.889 & 3.328 & & .868 & .391 & & \\
\hline & Pendapatan & .441 & .139 & .411 & 3.177 & .003 & .877 & 1.141 \\
\hline & Pengetahuan & .265 & .142 & .257 & 1.862 & .070 & .773 & 1.293 \\
\hline & Kesadaran & .187 & .126 & .195 & 1.484 & .146 & .851 & 1.175 \\
\hline
\end{tabular}

a. Dependent Variable: Kepatuhan

Sebagaimana telah dilakukan pengujian pada tebel tersebut, sehingga dapat dinyatakan bahwa:

1. Tingakat pendapatan mempunyai nilai tolerace sebesar 0,877

2. Pengetahuan mempunyai nilai tolerace sebesar 0,773

3. Kesadaran mempunyai nilai tolerace sebesar 0,851

Nilai tolerance setiap variabel $>$ dari 0,01sedangkan pada nilai VIF $<10,00$. Yang artinya bahwa dalam pengambilan sebuah keputusan ialah tidak terjadinya gejala multikolinearitas dalam riset ini.

\section{Uji Heteroskedastisitas}

\begin{tabular}{|c|c|c|c|c|c|c|}
\hline \multicolumn{7}{|c|}{$\begin{array}{c}\text { Tabel 9. Uji Heteroskedastisitas } \\
\text { Coefficients }^{\text {a }}\end{array}$} \\
\hline \multirow[b]{2}{*}{ Model } & & \multicolumn{2}{|c|}{ Unstandardized Coefficients } & \multirow{2}{*}{$\begin{array}{l}\text { Standardized } \\
\text { Coefficients } \\
\text { Beta }\end{array}$} & \multirow[b]{2}{*}{$t$} & \multirow[b]{2}{*}{ Sig. } \\
\hline & & B & Std. Error & & & \\
\hline \multirow[t]{4}{*}{1} & (Constant) & .509 & 1.935 & & .263 & .794 \\
\hline & Pendapatan & -.035 & .081 & -.072 & -.434 & .667 \\
\hline & Pengetahuan & .089 & .083 & .191 & 1.079 & .287 \\
\hline & Kesadaran & -.003 & .073 & -.006 & -.036 & .971 \\
\hline
\end{tabular}

a. Dependent Variable: Abs_RES

Sebagaimana telah dilaukan pengujian pada tebel tersebut, sehingga dapat dinyatakan bahwa dari variabel pengetahuan mempunyai tingkat signifikan sebesar 0,278, serta variabel kesadaran 0,971, yang artinya nahwa pada tingkat signifikan > dari 0,005 oleh karena itu, tidak terjadi heteroskedastisitas dalam riset ini. 


\section{Uji Hipotesis}

Tabel 10. Uji T (Parsial)

\begin{tabular}{|c|c|c|c|c|c|c|}
\hline \multicolumn{7}{|c|}{ Coefficients $^{a}$} \\
\hline & & \multicolumn{2}{|c|}{ Unstandardized Coefficients } & \multirow{2}{*}{$\begin{array}{c}\text { Standardized } \\
\text { Coefficients } \\
\text { Beta }\end{array}$} & \multirow[b]{2}{*}{$t$} & \multirow[b]{2}{*}{ Sig. } \\
\hline Model & & $\mathrm{B}$ & Std. Error & & & \\
\hline \multirow[t]{4}{*}{1} & (Constant) & 2.889 & 3.328 & & .868 & .391 \\
\hline & Pendapatan & .441 & .139 & .411 & 3.177 & .003 \\
\hline & Pengetahuan & .265 & .142 & .257 & 1.862 & .070 \\
\hline & Kesadaran & .187 & .126 & .195 & 1.484 & .146 \\
\hline
\end{tabular}

a. Dependent Variable: Kepatuhan

Sebagaimana telah dilaukan pengujian pada tebel tersebut, sehingga dapat dinyatakan bahwa variabel tingkat pendapatan mempunyai tingkat signifikan sebesar 0,03 serta memliki

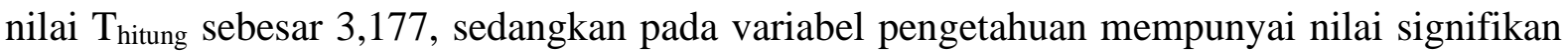
sebesar 0,070 dengan mempunyai nilai $\mathrm{T}_{\text {hitung }}$ sebesar 1,862 sedangkan pada variabel kesadaran mempunyai tingkat signifikan sebesar 0,146 dengan mempunyai nilai $\mathrm{T}_{\text {hitung }}$ sebesar 1,484. Oleh karena itu dapat dinyatakan bahbwa variabel pendapatan dapat memberikan pengaruh yang secara signifikan terhadap kepatuhan WP.

\section{Uji F (Simultan)}

\begin{tabular}{|c|c|c|c|c|c|c|}
\hline \multicolumn{7}{|c|}{$\begin{array}{c}\text { Tabel 11. Uji F (Simultan) } \\
\text { ANOVA }^{\mathbf{a}}\end{array}$} \\
\hline \multicolumn{2}{|l|}{ Model } & $\begin{array}{l}\text { Sum of } \\
\text { Squares }\end{array}$ & df & Mean Square & $\mathrm{F}$ & Sig. \\
\hline \multirow[t]{3}{*}{1} & Regression & 111.865 & 3 & 37.288 & 9.389 & $.000^{b}$ \\
\hline & Residual & 158.863 & 40 & 3.972 & & \\
\hline & Total & 270.727 & 43 & & & \\
\hline
\end{tabular}

a. Dependent Variable: Kepatuhan

b. Predictors: (Constant), Kesadaran, Pendapatan, Pengetahuan

Sebagaimana telah dilaukan pengujian pada tebel tersebut, sehingga dapat dinyatakan bahwa pada tingkat signifikan sebesar $0,000<0,05$, sedangkan nilai $\mathrm{T}_{\text {hitung }} 9,399>\mathrm{T}_{\text {tabel }}$, sehingga dapat disimpulkan bahwa secara bersama-sama variabel pendapatan, pengetahuan serta kesadaran berpengaruh terhadap terhadap kepatuhan WP. 


\section{Koefisien Determinasi (R Square)}

Tabel 12. Koefisien Determinasi

\begin{tabular}{l|l|r|c|r}
\multicolumn{7}{c}{ Model Summary } \\
Model & R & R Square & $\begin{array}{c}\text { Adjusted R } \\
\text { Square }\end{array}$ & $\begin{array}{c}\text { Std. Error of } \\
\text { the Estimate }\end{array}$ \\
\hline 1 & $.643^{\text {a }}$ & .413 & .369 & 1.993 \\
\hline \multicolumn{3}{c}{ a. Predictors: (Constant), Kesadaran, Pendapatan, } \\
Pengetahuan
\end{tabular}

Sebagaimana telah dilaukan pengujian pada tebel tersebut, sehingga dapat dinyatakan bahwa pada nilai koefisien determinasi atau R Square ialah sebesar 0,413 atau 41,3\%, yang artinya bahwa kepatuhan WP dapat diprediksi oleh variabel pendapata, pengetahuan serta kesadaran sebesar 41,3\%, sedangkan yang sisanya 58,7\% dipengaruhi oleh faktor lain diluar riset ini.

\section{Pembahasan}

\section{Pengaruh Tingkat Pendapatan Terhadap Kepatuhan Wajib Pajak}

Sebagai mana pada hasil analisa yang dilakukan dalam riset ini, sehingga dalam pembahasan yang ada, maka dapat disimpulkan bahwa variabel tingkat pendapatan dapat memberikan pengaruh yang secara signifikan pada kepatuhan WP, sehingga hipotesis $\mathrm{H}_{1}$ diterima. Oleh karena itu pada kesimpulannya ialah variabel tingkat pendapatan dapat memberikan pengaruh yang secara signifikan pada kepatuhan WP. Riset ini serupa dengan apa yang dilkaukan oleh (Amran, 2018) yang mengatakan bahwa tingkat pendapatan dapat memberikan pengaruh yang signifikan sertas memberikan tanda yang positif terhadap kepatuhan WP. (Amran, 2018b)Apabila terdapat sebauh peningkatan pada sebuah pendapatan maka secara tidak langsung akan berdampak pada kepatuhan WP

\section{Pengaruh Pengetahuan terhadap Kepatuhan Wajib Pajak}

Sebagai mana pada hasil analisa yang dilakukan dalam riset ini, sehingga dalam pembahasan yang ada, maka dapat disimpulkan bahwa variabel pengetahuan tidak dapat memberikan pengaruh yang secara signifikan pada kepatuhan WP, sehingga pada keputasan hopitesisnya ialah $\mathrm{H} 2$ ditolak. Oleh karena itu pada kesimpulannya ialah variabel 
pengetahuan tidak dapat memberikan pengaruh yang secara signifikan pada kepatuhan WP. Riset ini tidak sajalan dengan riset yang dilakukan oleh (Rizki Indrawan Dan Bani Binekas, 2018) yang menyatakan bahwa pengetahun perpajakn dapat memberikan pengaruh secara signifikan terhadap kepatuhan WP.

\section{Pengaruh Kesadaran Terhadap Kepatuhan Wajib Pajak}

Sebagai mana pada hasil analisa yang dilakukan dalam riset ini, sehingga dalam pembahasan yang ada, maka dapat disimpulkan bahwa variabel kesadaran tidak dapat memberikan pengaruh yang secara signifikan pada kepatuhan WP, sehingga pada keputasan hopitesisnya ialah H3 ditolak. Oleh karena itu pada kesimpulannya ialah variabel kesadarantidak dapat memberikan pengaruh yang secara signifikan pada kepatuhan WP. Riset ini tidak sejalan dengan riset yang dilakukan oleh (Aryo Prakoso, Galih Wicaksono \& Yeni Puspita, Sandhika Cipta Bidhari, 2019), (Zulaicha Efrita Sarasawati, 2018) yang menyatakan bahwa kesasadaran dapat memberikan pengaruh yang signifikan terhadap kepatuhan WP.

\section{KESIMPULAN}

Berdasarkan hasil penelitian dan pembahasan yang telah dilakukan, dapat ditarik kesimpulan bahwa tingkat pendapatan berpengaruh signifikan terhadap kepatuhan WP di Kelurahan Polowijen, pengetahuan tidak berpengaruh signifikan terhadap kepatuhan WP di Kelurahan Polowijen dan kesadaran tidak berpengaruh signifikan terhadap kepatuhan WP di Kelurahan Polowijen.

\section{DAFTAR PUSTAKA}

Amran. (2018a). Pengaruh Sanksi Perpajakan, Tingkat Pendapatan dan Kesadaran Wajib Pajak terhadap Kepatuhan Wajib Pajak Orang Pribadi. Ilmiah Akuntansi, 1(1), 1-15.

Amran. (2018b). Pengaruh Sanksi Perpajakan, Tingkat Pendapatan Dan Kesadaran Wajib Pajak Terhadap Kepatuhan Wajib Pajak Orang Pribadi (Studi Pada Kantor Pelayanan Pajak Pratama Makasar Utara). Junal Ilmiah Akuntansi, 1(2), 1-15. e-ISSN: 2621-1505 p-ISSN: 2621-1906.

Aryo Prakoso, Galih Wicaksono, S. I., \& Yeni Puspita, Sandhika Cipta Bidhari, N. D. K. (2019). Pengaruh Kesadaran Dan Pengetahuan Wajib Pajak Terhadap Kepatuhan Wajib Pajak. Jurnal Akuntansi \& Ekonomi FE UN PGRI Kediri, 4(2), 1-17. ISSN: 2451-0180.

Arifin, S. B., \& Nasution, A. A. (2017). Pengaruh Kualitas Pelayanan dan Sanksi Perpajakan Terhadap kepatuhan Wajib Pajak Badan di KPP Pratama Medan belawan. Jurnal Akuntansi Dan Bisnis: Jurnal Program Studi Akuntansi, 3(2). 
Artha, K. G. W., \& Setiawan, P. E. (2016). Pengaruh Kewajiban Moral, Kualitas Pelayanan, Sanksi Perpajakan Pada Kepatuhan Wajib Pajak Di KPP Badung Utara. E-Jurnal Akuntansi, 17(2), 913-937.

Erawati, T., \& Parera, A. M. W. (2017). Pengaruh Kesadaran Wajib Pajak, Sanksi Perpajakan, Pengetahuan Perpajakan, dan Pelayanan Fiskus. Jurnal Akuntansi, 5(1), 37-48.

Ermawati, N., \& Afifi, Z. (2018). Pengaruh Pengetahuan Perpajakan dan Sanksi Perpajakan Terhadap Kepatuhan Wajib Pajak Dengan Religiusitas Sebagai Variabel Pemoderasi.

Hermawati, A. (2014). Analisis Faktor untuk meningkatkan penerimaan pajak penghasilan dan implikasinya terhadap peningkatan penerimaan negara.

Hermawati, A., \& Gunawan, E. (2020). The implementation of dynamic capabilities for small and medium-sized enterprises in creating innovation. VINE Journal of Information and Knowledge Management Systems.

Muhamad, M. S., Asnawi, M., \& Pangayow, B. J. (2019). Pengaruh Sosialisasi Perpajakan, Tarif Pajak, Sanksi Perpajakan, Dan Kesadaran Perpajakan Terhadap Kepatuhan Pelaporan SPT Tahunan Wajib Pajak Orang Pribadi. Jurnal Akuntansi dan Keuangan Daerah, 14(1), 69-86.

Nuraina, F. S. E. (2017). Pengaruh sanksi perpajakan terhadap kepatuhan wajib pajak orang pribadi di Kantor Pelayanan Pajak Pratama Madiun. EQUILIBRIUM: Jurnal Ilmiah Ekonomi dan Pembelajarannya, 5(1), 45-55.

Pebrina, R., \& Hidayatulloh, A. (2020). Pengaruh Penerapan E-SPT, Pemahaman Peraturan Perpajakan, Sanksi Perpajakan dan Kualitas Pelayanan Terhadap Kepatuhan Wajib Pajak. Jurnal Ilmiah Ekonomi Dan Bisnis, 17(1), 1-8.

Paramartha, I. P. I. P., \& Rasmini, N. K. (2016). Pengaruh kualitas pelayanan, pengetahuan dan sanksi perpajakan pada kepatuhan wajib pajak badan. E-Jurnal Akuntansi Universitas Udayana, 15(1), 641-666.

Putri, K. J., \& Setiawan, P. E. (2017). Pengaruh Kesadaran, Pengetahuan Dan Pemahaman Perpajakan, Kualitas Pelayanan Dan Sanksi Perpajakan Terhadap Kepatuhan Wajib Pajak. E-Jurnal Akuntansi Universitas Udayana, 18(2), 1112-1140.

Rizki Indrawan Dan Bani Binekas. (2018). Pemahaman Pajak dan Pengetahuan Pajak Terhadap Kepatuhan Wajib Pajak UKM Understanding of Taxes and Knowledge of Taxes on Compliance with SME Taxpayers. Jurnal Riset Akuntansi Dan Keuangan, 6(3), 419-428. ISSN:2541-061X (Online). ISSN:2338-1507(P.

Siahaan, S., \& Halimatusyadiah, H. (2018). Pengaruh Kesadaran Perpajakan, Sosialisasi Perpajakan, Pelayanan Fiskus, Dan Sanksi Perpajakan Terhadap Kepatuhan Wajib Pajak Orang Pribadi. Jurnal Akuntansi, 8(1), 1-14.

Siamena, E., Sabijono, H., \& Warongan, J. D. (2017). Pengaruh sanksi perpajakan dan kesadaran wajib pajak terhadap kepatuhan wajib pajak orang pribadi di Manado. Going Concern: Jurnal Riset Akuntansi, 12(2).

Zulaicha Efrita Sarasawati, E. M. D. R. R. D. (2018). Pengaruh Kesadaran Pajak, Sistem Administrasi Pajak Modern Dan Sanksi Pajak Terhadap Kepatuhan Wajib Pajak Pada Umkm Di Surakarta. Jurnal Studi Kasus Inovasi Ekonomi, 2(3), 45-52. P-ISSN: 25286269 E-ISSN: 2623-2103. 